\title{
Job thifetime
}

\section{Yours, mine, and ours: Reinventing reference at San José}

This month "Job of a Lifetime" looks at a major midcareer challenge-reinventing your library service. Christina Peterson currently serves as academic services librarian at the Dr. Martin Luther King Jr. Library. The King Library is a joint-use facility run by San José State University (SJSU) Library and the San José Public Libraries, serving the students and faculty of SJSU as well as the city of San José.

\section{Out of the blue}

Peterson began as health sciences librarian at SJSU Library back in 1986. "I would have to say that before the merge we were a rather typical academic library, where a person in my position would be doing reference to the general student body as well as collection management and library instruction as liaison to specific departments.

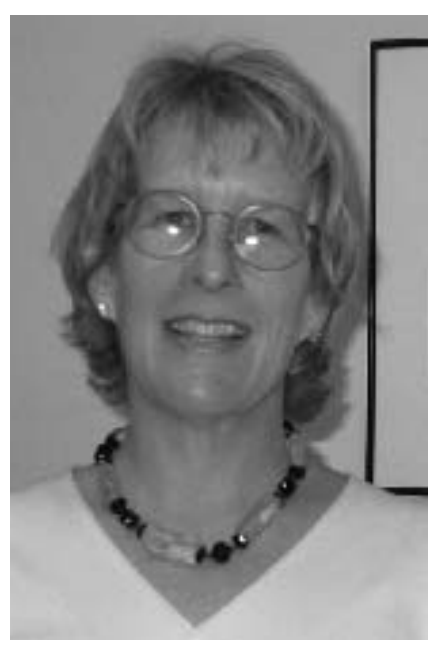

Christine Peterson, academic services librarian at the Dr. Martin Luther King Jr. Library at San José State University. academic library person managing all the subteams that planned user services: reference services, what the combined Web site would look like, how the public access computers would be configured, how the meeting rooms and group study rooms would be used, etc."

\section{Paradigm shift}

About two months into the process, Peterson experienced a watershed moment. "Everyone had this almost daily walk back and forth between the libraries for meetings, where we were questioning everything. Why do we offer our services in this way? Are there other ways that we can accomplish the same goal? Why do we do this? What purpose is that serving?

Walking back from one of those meetings, I experienced the distinct physical manifestaYou know, you work in a library that's been there for 130 or 140 years and you've done things in the way you've done them forever. We all woke up one February morning in 1997 and read in the San Jose Mercury News that we would be part of this merge. It was a surprise to almost everybody in the library."

Peterson was made the cochair of the User Services Team that planned all the public services for the new building. Peterson recalled, "I plunged into the planning process.

My co-team leader was Lisa Rosenblum, who is now the supervising librarian for King Library. We had a public library and an tion of examining issues from a new angle. I'll never forget feeling my brain go 'click, click, click, click' and make a 90 degree turn; then I began to accept new ways of thinking about library services."

\section{A whole new body}

Peterson observed that it was a long process-seven years from the initial announcement to date. "Seven years, which is the

Danianne Mizzy is assistant head of the Engineering Library at the University of Pennsylvania. Have an idea for a "Job of a Lifetime" story? E-mail: danianne@seas. upenn.edu. 
amount of time it takes for all the cells in your body to turn over. I can't say that every single cell of my work life turned over, but a good percentage of them have. It was really a learning process for me. It turned out that I was pretty good at consensus building and bringing teams together. I was able to maintain academic priorities in a complex situation. I discovered that I could help small groups understand why one side or the other provided services in a certain way and how to provide services in a mutual way. When things didn't dovetail we worked around it, pushed them together, fixed them, and tried different configurations."

Peterson outlined how her thinking evolved over the fouryear planning process. "At the beginning, I viewed my particular constituency as the health science students, but over time it broadened out quite a bit. We all worked hard to fully understand the differing objectives and clientele of the public and the academic libraries. In terms of reference service, there's the continuum between completely answering the question and teaching users to become independent researchers.

"Another difference is the way reference librarians in the public library and the academic library learn to value their work. Academic reference librarians value their expertise in a specific subject area. Public reference librarians value their generalist abilities. The first decision to have one reference desk was a model for all the rest of the things we went through. We decided that as much as possible we would have a public librarian and an academic librarian serving together on the reference desk, learning from each other how to handle each other's types of questions."

In a parallel process, Peterson explained, "the SJSU library examined what made us unique academically and what the campus valued in the library as an academic entity."
This culminated in the 15-point statement "Affirming Academic Responsibilities."

"The library faculty is safeguarding these academic responsibilities," stated Peterson, "and I'm proud of us doing that."

\section{Librarian, team leader, teacher, scholar}

Peterson will be adding yet another role to her responsibilities in the upcoming academic year. She is the first librarian at SJSU to receive the honor of being named a Teacher Scholar. The Teacher Scholar award allows outstanding teachers to engage in midcareer reflective discussion on teaching and learning and to examine and conduct research on teaching and learning. "This is really very exciting for me," Peterson shared, "to join my instructional colleagues. We will develop a research project during the course of this academic year, and I suspect it is going to have something to do with the effect of culture on learning."

\section{Rainbow connection}

If your travels bring you to California, Peterson extended the following invitation. "Please come see this beautiful library. The idea of this building is to foster lifelong learning. Students bring their children in to the children's room, they bring their parents and grandparents in to the adult services area. It means that working here is more holistic and more like real life. We also have a wonderful public art collection.

"And, because of the way the architects situated windows and glass, there are rainbows that spontaneously appear all over the building. There will be students with rainbows on them while they're studying and, at certain times of the day, you have a rainbow on yourself, too, as you sit at the reference desk."

So there is gold at the end of the rainbow, at least in San José. $\mathbf{z}$ 